九州大学学術情報リポジトリ

Kyushu University Institutional Repository

\title{
Genome-analytic studies on Brassica trilocularis and B. tournefortii
}

Fukushima, Eiji

Horticultural Laboratory, Department of Agriculture, Kyushu University

Iwasa, Shoichi

Horticultural Laboratory, Department of Agriculture, Kyushu University

https://doi.org/10.5109/22743

出版情報: 九州大学大学院農学研究院紀要. 13 (4)，pp.743-748，1966-02. Kyushu University バージョン：

権利関係 : 


\title{
Journal of the Faculty of Agriculture, Kyushu University, Vol. 13, No. 1, February 15, 1966
}

\section{Genome-analytic studies on Brassica trilocularis and $B$. tournefortii*}

\author{
Eiji Fukushima and Shoichi Iwasa
}

The group of Brassica species with 10 pairs of chromosomes includes, like the cole group, a large number of cultivated species, and the most species are composed of genome $a$, excepting only a few species (Morinaga 1934, Sikka 1940). According to the opinion of Olsson (1954), B. tournefortii will be considered to be a separate species, while all the other species with 10 pairs of chromosomes, viz., B. pekinensis, B. chinensis, $B$. narinosa, $B$. nipposinica, $B$. campestris and $B$. trilocularis, are to be subspecific forms of $B$. campestris s. lat.

The authors' investigation on the genetic differentiation in the group of Brassica species with 10 pairs of chromosomes was started with the examination of $\boldsymbol{B}$. tournefortii and $\boldsymbol{B}$. trilocularis to elucidate the cytogenetical relationship established between these two forms and several other species in Brassica.

\section{Materials and method}

The materials used in the present crossing experiment are as follows: Brassica campestris var. oleifera (hort. var., Kanzaki-hanana), $\boldsymbol{B}$. tournefortii, B. trilocularis, B. nigra (hort. var., California brown) and $\boldsymbol{B}$. alboglabra. All these forms used as materials showed exclusively normal meiotic division processes and could produce ca. 95 or still higher percentage of the well-stainable pollen-grains.

Crossings were effected by the bud-pollination technique. Cytological observations were made with the preparations made by the smear method with acetic-orcein.

* Contribution from the Horticultural Laboratory, Faculty of Agriculture, Kyushu University. 


\section{Results}

1. The result of crossings and certain characteristics in the $F_{1}$ hybrids.

As shown in Table $1, B$. tournefortii crossed with $B$. nigra or with $B$. alboglabra failed to yield any one true $F_{1}$ seed, while 3 other forms with 10 pairs of chromosomes, i. e., B. campestris, B. trilocularis and $\boldsymbol{B}$. tournefortii, when crossed among each others, could raise certain true $F_{1}$ seeds. This table shows, in advance, that $B$. tournefortii was highly cross-incompatible with Brassica forms composed of $a, b$ or $c$ genome and also that $\boldsymbol{B}$. trilocularis was, in contrast, highly cross-compatible with $a$ genome species. Certain outstanding characteristics appearing in these parents and their $F_{1}$ hybrids are shown in Table 2.

2. The meiotic divisions in PMCs and the fertility of $F_{1}$ hybrids.

Table 1. Results of crossing experiments.

\begin{tabular}{|c|c|c|c|c|c|c|}
\hline \multirow{2}{*}{$\begin{array}{l}\text { Cross } \\
\text { combination }\end{array}$} & \multirow{2}{*}{$\begin{array}{l}\text { Number } \\
\text { of flowers } \\
\text { pollinated }\end{array}$} & \multirow{2}{*}{$\begin{array}{l}\text { Number } \\
\text { of pods } \\
\text { developed }\end{array}$} & \multirow{2}{*}{$\begin{array}{l}\text { Number } \\
\text { of seeds } \\
\text { obtained }\end{array}$} & \multirow{2}{*}{$\begin{array}{l}\text { Number } \\
\text { of seeds } \\
\text { sown }\end{array}$} & \multicolumn{2}{|c|}{$\begin{array}{c}\text { Number of plants } \\
\text { grown }\end{array}$} \\
\hline & & & & & $\begin{array}{l}\text { true } \\
\text { hybrid }\end{array}$ & $\begin{array}{l}\text { false } \\
\text { hybrid }\end{array}$ \\
\hline $\begin{array}{l}\text { B. trilocularis } \\
\times \text { B. tournefortii } \\
\times B \text {. campestris }\end{array}$ & $\begin{array}{l}36 \\
25\end{array}$ & $\begin{array}{l}10 \\
21\end{array}$ & $\begin{array}{r}3 \\
112\end{array}$ & $\begin{array}{r}3 \\
40\end{array}$ & $\begin{array}{r}0 \\
40\end{array}$ & $\begin{array}{l}3 \\
0\end{array}$ \\
\hline $\begin{array}{l}\text { B. tournefortii } \\
\times \text { B. campestris } \\
\times \text { B. trilocularis } \\
\times \text { B. alboglabra } \\
\times B . \text { nigra }\end{array}$ & $\begin{array}{l}56 \\
28 \\
36 \\
25\end{array}$ & $\begin{array}{l}26 \\
21 \\
18 \\
20\end{array}$ & $\begin{array}{r}9 \\
11 \\
24 \\
14\end{array}$ & $\begin{array}{r}9 \\
11 \\
24 \\
14\end{array}$ & $\begin{array}{l}1 \\
5 \\
0 \\
0\end{array}$ & $\begin{array}{r}3 \\
2 \\
18 \\
8\end{array}$ \\
\hline
\end{tabular}

Table 2. Certain characteristics as compared among B. campestris,

$B$. trilocularis, $B$. tournefortii and their respective $F_{1}$ hybrids.

\begin{tabular}{|c|c|c|c|c|c|c|}
\hline & Basal leaf & Upper 1caf & Petal & Anther & Pod & Seed \\
\hline B. campestris & $\begin{array}{l}\text { light green, } \\
\text { pubescent }\end{array}$ & $\begin{array}{l}\text { oblong, } \\
\text { clasping }\end{array}$ & $\begin{array}{l}\text { wide, } \\
\text { yellow }\end{array}$ & extrosed & $\begin{array}{c}\text { large, cy- } \\
\text { lindrical }\end{array}$ & brown \\
\hline B. trilocularis & $\begin{array}{l}\text { dark green, } \\
\text { globrous }\end{array}$ & $\begin{array}{l}\text { oblong, } \\
\text { clasping }\end{array}$ & $\begin{array}{l}\text { wide, } \\
\text { yellow }\end{array}$ & introsed & $\begin{array}{l}\text { large, } \\
\text { flat }\end{array}$ & yellow \\
\hline B. tournefortii & $\begin{array}{l}\text { green, } \\
\text { pubescent }\end{array}$ & $\begin{array}{l}\text { narrow, not } \\
\text { clasping }\end{array}$ & $\begin{array}{l}\text { narrow, } \\
\text { pale }\end{array}$ & introsed & $\begin{array}{l}\text { small, } \\
\text { compres- }\end{array}$ & brown \\
\hline (B. camp.-tri.) $\mathrm{F}_{1}$ & $\begin{array}{l}\text { green, } \\
\text { pubescent }\end{array}$ & $\begin{array}{l}\text { intermedi- } \\
\text { ate, clasp- } \\
\text { ing }\end{array}$ & $\begin{array}{l}\text { yellow } \\
\text { intermedi- } \\
\text { ate, } \\
\text { yellow }\end{array}$ & extrosed & $\begin{array}{l}\text { sed } \\
\text { intermedi- } \\
\text { ate }\end{array}$ & \\
\hline (B. camp.-tour.) I & $F_{1} \underset{\text { pubescent }}{\text { light green, }}$ & $\begin{array}{l}\text { intermedi- } \\
\text { ate, not } \\
\text { clasping }\end{array}$ & $\begin{array}{l}\text { intermedi- } \\
\text { ate, pale } \\
\text { yellow }\end{array}$ & extrosed & & \\
\hline (B. tri.-tour.) $\mathrm{F}_{1}$ & $\begin{array}{l}\text { green, } \\
\text { pubescent }\end{array}$ & $\begin{array}{l}\text { intermedi- } \\
\text { ate, not } \\
\text { clasping }\end{array}$ & $\begin{array}{l}\text { intermedi- } \\
\text { ate, pale } \\
\text { yellow }\end{array}$ & introsed & & \\
\hline
\end{tabular}


Table 3. Chromosome pairings at meiotic metaphase-I in PMCs of the $\mathrm{F}_{1}$ hybrids.

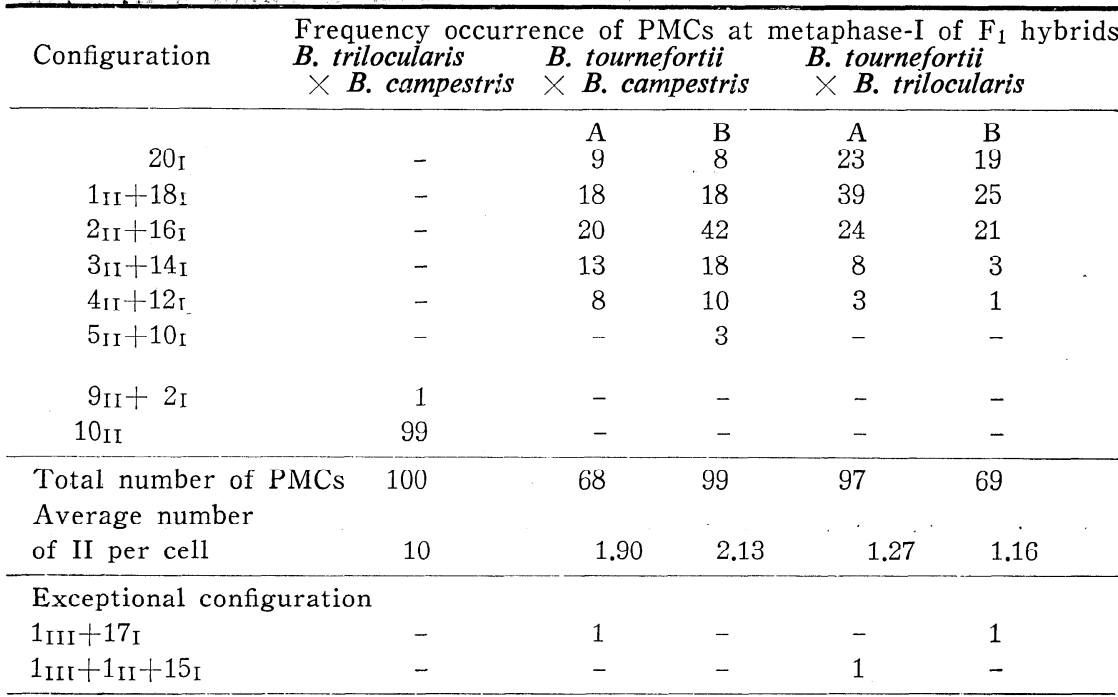

N. B. A and B denote the different dates of observation with the same individuals.

(1) $\mathrm{F}_{1}$ B. trilocularis $\times$ B. campestris: There were found 10 bivalents formed at MI, of which 1 or 2 were often loosely paired (Fig. 1). Univalents rarely occurred in case of faulty pairings (Fig. 2, Table 3). The mode of chromosome distribution at AI towards the sister nuclei was 10-10 in most cells, being 9-11 in rare cases, so that the subsequent division processes could proceed quite normally, but examinations given thrice with a weekly interval revealed that pollen-fertilities, as designated by the frequency occurrence of well-stainable pollen-grains, did not exceed $80 \%$, i. e., $76.9,76.8$ and $79.2 \%$, respectively. The average seed-fertility, denoted by the percentage value of viable seeds per ovule formed, attained to $27.6 \%$ under the open-pollination.

(2) $\mathrm{F}_{1}$ B. tournefortii $\times$ B. campestris: The configuration obtained at MI was mainly composed of loosely associated bivalents and several univalents (Figs. 3,4), and the maximum number of bivalents per cell attained to 5 . In some rare cases a trivalent appcarcd. The occurrence of a large number of univalents at MI resulted no doubt in the remarkable irregularity in the subsequent division processes, so that there were observed at the pollen-tetrad stage various kinds of sporads, ranging from monad to hexad, diads being fairly high in its frequency appearance. Both the pollen- and seed-fertilities became to be almost nil.

(3) $\mathrm{F}_{1}$ B. tournefortii $\times$ B. trilocularis: The configuration at $\mathrm{MI}$ in this 
$F_{1}$, being just like that obtained in the $F_{1}, B$. tournefortii $\times B$. campestris, was composed of a few loosely paired bivalents (0-4) and many univalents (20-12), with rare occurrence of a trivalent (Figs. 5, 6). The subsequent divisions were effected in the similar way in this $F_{1}$ as in the preceding $F_{1}$, excepting the quite frequent appearance of diads and triads. Diads showed rather more frequent occurrence as compared with the normal tetrads in some anthers examined. It appears likely that the occurrence of diads would bring about the formation of nonreductive gametes, because nearly half of pollen-grains produced in a fairly developed anther locule appeared to be quite viable in good contrast to the rest degenerated ones occurring with them.

\section{Discussion}

The 10-chromosome forms of Brassica, e. g., B. pekinensis, B. rapa, B. chinensis, B. japonica, B. narinosa, B. campestris etc., can cross easily with each other, resulting in the production of quite fertile $F_{1}$ hybrid plants, which show remarkable differences in their various characteristics (Sinskaia 1927, Morinaga 1928, Sikka 1940, Olsson 1954). Excepting the authors' $F_{1}$ hybrid plants reported herewith, the $2 F_{1}$ hybrid plants had been obtained by Sikka (1940) through the crossing, B. tournefortii $\times B$. trilocularis, though a number of crossings between $\boldsymbol{B}$. tournefortii and the other Brassica forms have been tried by several workers.

The interrelationship existing among B. campestris, B. trilocularis and $B$. tournefortii, as presumed from the manner of chromosome pairings in these $F_{1}$ hybrids, may be summarized as follows: (1) The genome of $\boldsymbol{B}$. trilocularis will be considered to be homologous to that of $\boldsymbol{B}$. campestris with very slight difference. A slight mciotic irregularity observable in the $F_{1} B$. trilocularis $\times B$. campestris could also be recognized in the $F_{1} B$. rapa $\times$ B. trilocularis (Sikka 1940), in the $F_{1} B$. campestris (var. oleifera, var. toria) $\times B$. trilocularis and in the $F_{1} B$. chinensis $\times B$. trilocularis (Olsson 1954), and in the $\mathrm{F}_{1}$ B. pekinensis $\times$ B. rapa (Richharia 1937). Most of the interspecific $F_{1}$ hybrids in Brassica having 10 pairs of chromosomes showed rather normal meiotic behaviours and the resultant high fertility, but the remaining several hybrids showed certain meiotic irregularities and resulted in the reduced fertility, probably because of various degree of genetic differentiations which have taken place within the genome $a$. B. trilocularis showed, however, rather definite difference from the typical $a$ genome species in the following characteristics; the general morphology, the self-fertile reproductiveness, and certain biochemical features of the methanol-soluble leaf extract (cf. Sinskaia 1928, Alam 1945, Fukushima and Iwasa 1965). Olsson (1954) has destined this form as a good subspecies of B. campestris in clearcut contrast to any other forms. Thus the authors 
would prefer to give the designation $\boldsymbol{a}^{\prime}$ to this genome of $\boldsymbol{B}$. trilocularis. (2) The authors' investigation has disclosed that $B$. tournefortii was fairly different in its genome constitution from either of $B$. campestris or $B$. trilocularis. Thus the designation $T$ was duly given to the genome of $B$. tournefortii.

As shown in Table 3, from the rather rare appearance of a trivalent chromosome in the PMC of $\mathrm{F}_{1}$ hybrid it may be duly conceivable that one bivalent would be possible to occur as an autosyndetic pairing within either one of the genomes $T, a$ or $\boldsymbol{a}^{\prime}$. Ramanujam (1941) found rarely in his haploid mutant of $B$. campestris one single bivalent which may be produced by an autosyndesis within $a$ genome. If so, it would naturally follow that each two of bivalents formed in the $F_{1} B$. tournefortii $\times B$. trilocularis and in the $F_{1} B$. tournefortii $\times B$. campestris are the product of autosyndetic pairings. In consequence, granted that such two autosyndetic bivalents will occur at most the formation of two or three allosyndetic bivalents in the $F_{1}$ hybrids would be taken as the proved fact from the maximum chromosome pairings at MI. The observations described above will support no doubt that the genome $T$ is partially homologous to $a$ and $\boldsymbol{a}^{\prime}$ genomes.

\section{Summary}

The authors have tried to raise interspecific crosses between $B$. trilocularis or B. tournefortii and several other Brassica species, and succeeded in obtaining true $F_{1}$ hybrids in the following three cross-combinations: $B$. tournefortii $\times B$. campestris, $B$. tournefortii $\times B$. trilocularis and $B$. trilocularis $\times B$. campestris. $B$. tournefortii was highly cross-incompatible with Brassica species having $a, b$ or $c$ genome, and $B$. trilocularis was, in turn, highly cross-compatible with Brassica species having $a$ genome. Meiotic chromosome associations obtained with those $\mathrm{F}_{1}$ hybrids were $(0-4)_{\mathrm{II}}+(20-12)_{\mathrm{I}}$ in $\mathrm{F}_{1} B$. tournefortii $\times B$. trilocularis, $(0-$ $5)_{\mathrm{II}}+(20-10)_{\mathrm{I}}$ in $F_{1}$ B. tournefortii $\times B$. campestris and $(9-10)_{\mathrm{II}}+(2-0)_{\mathrm{I}}$ in $F_{1}$ B. trilocularis $\times$ B. campestris.

The result of genome-analysis has made clear that $B$. tournefortii is composed of the genome $T$, being partially homologous with the genome $a$, and that the genome $a^{\prime}$ of $B$. trilocularis is taken as that distinctly different from the genome $a$, though rather slight in its degree.

\section{Literature cited}

Alam, Z. 1945. Nomenclature of oleiferous brassicas cultivated in the Punjub. Indian Jour. Agr. Sci. 15: 173-181.

Fukushima, E. and S. Iwasa 1965. A chromotographic study of Brassica species having 10 pairs of chromosomes in somatic. Jour. Fac. Agr. Kyushu Univ. 
13: 749-756.

Morinaga, T. 1928. Preliminary note on interspecific hybridization in Brassica. Proc. Imp. Acad. Japan 4:620-622.

- 1934. Interspecific hybridization in Brassica. VI. The cytology of $\mathrm{F}_{1}$ hybrids of $B$. juncea and $B$. nigra. Cytologia 6: 62-67.

Olsson, G. 1954. Crosses within the campestris group of the genus Brassica. Heredi$\operatorname{tas} 40: 398-418$.

Richharia, R. H. 1937. Cytological investigation of 10-chromosome species of Brassica and their $\mathrm{F}_{1}$ hybrids. Jour. Genet. 34 : 45-55.

Sikka, S. M. 1940. Cytogenetics of Brassica hybrids and species. Jour. Genet. 40: 441-509.

Sinskaia, E. N. 1927. Geno-systematical investigations of cultivated Brassica. Bull. Appl. Bot. Genet. Pl. Breed. 17 : 1-166.

1928. The oleiferous plants and root crops of the family Cruciferae. Ibid. $19: 1-648$.

Explanation of Plate 14

Flowering plants of $\mathrm{F}_{1}$ hybrids and their parents.

a, B. tournefortii; b, $\mathrm{F}_{1}$ hybrid of $B$. tournefortii $\times$ B. campestris; c, $\mathrm{F}_{1}$ hybrid of $B$. tournefortii $\times B$. trilocularis; d, $B$. trilocularis; e, $\mathrm{F}_{1}$ hybrid of $B$. trilocularis $\times B$. campestris; $\mathrm{f}, B$. campestris. 


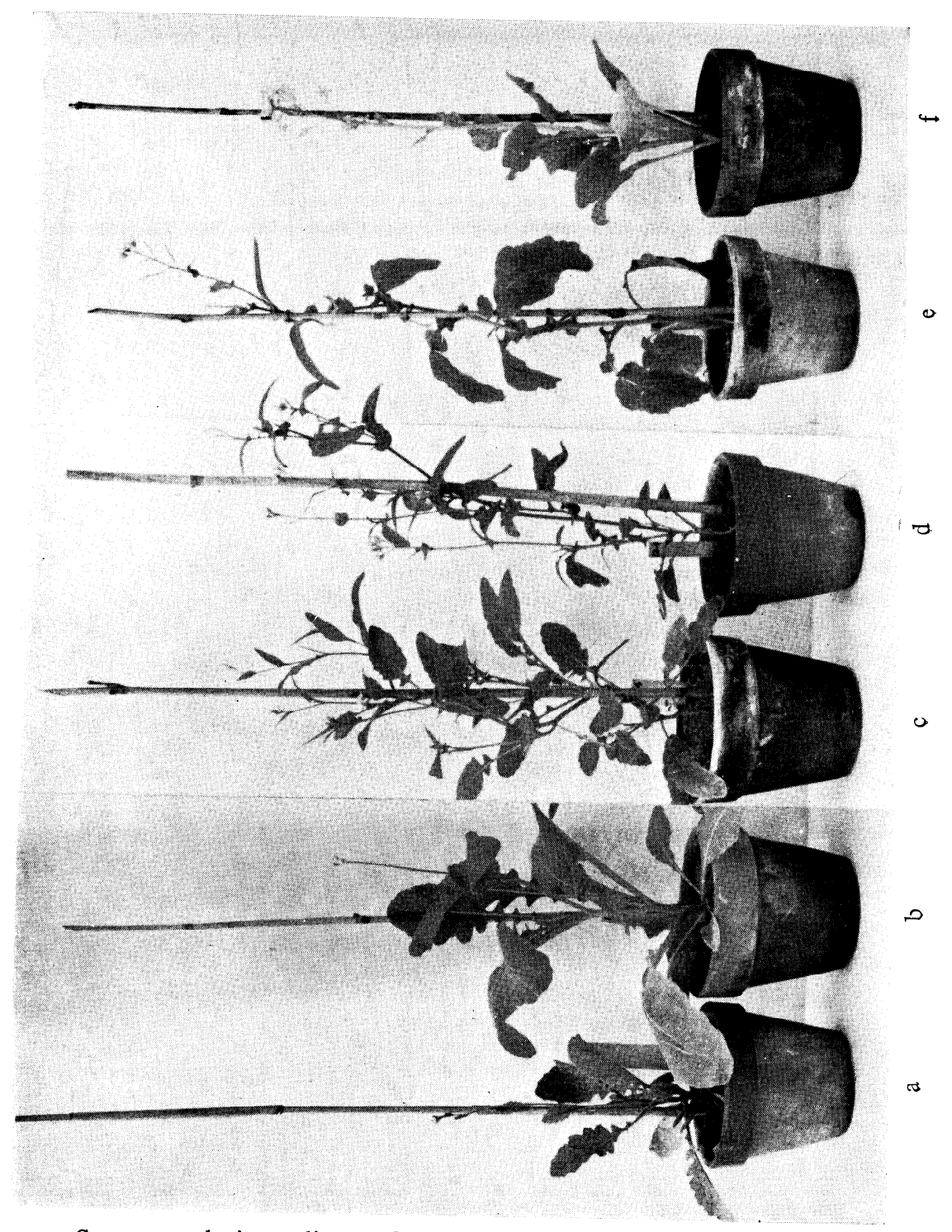

Genome-analytic studies on Brassica trilocularis and B. tournefortii 
Explanation of Platc 15

Microphotographs of metaphase-I in PMCs of $F_{1}$ hybrids, $B$. trilocularis $\times$ B. campestris (Figs. 1 and 2), B. tournefortii $\times$ B. trilocularis (Figs 3 and 4), and $B$. tournefortii $\times$ B. trilocularis (Figs 5 and 6 ).

Fig. 1.10 ${ }_{\mathrm{II}}$, containing two loose bivalents. Fig. 2. $9_{\mathrm{II}}+2_{\mathrm{I}}$. Fig. $3 . \mathrm{I}_{\mathrm{II}}+18_{\mathrm{I}}$. Fig. 4. 4II $+12_{\mathrm{I}}$. Fig. 5. 20 II. Fig. 6. III $_{\mathrm{II}} \mid-17_{\mathrm{I}}$. 
Jour. Fac. Agric., Kyushu Univ., Vol. 13

Plate 15

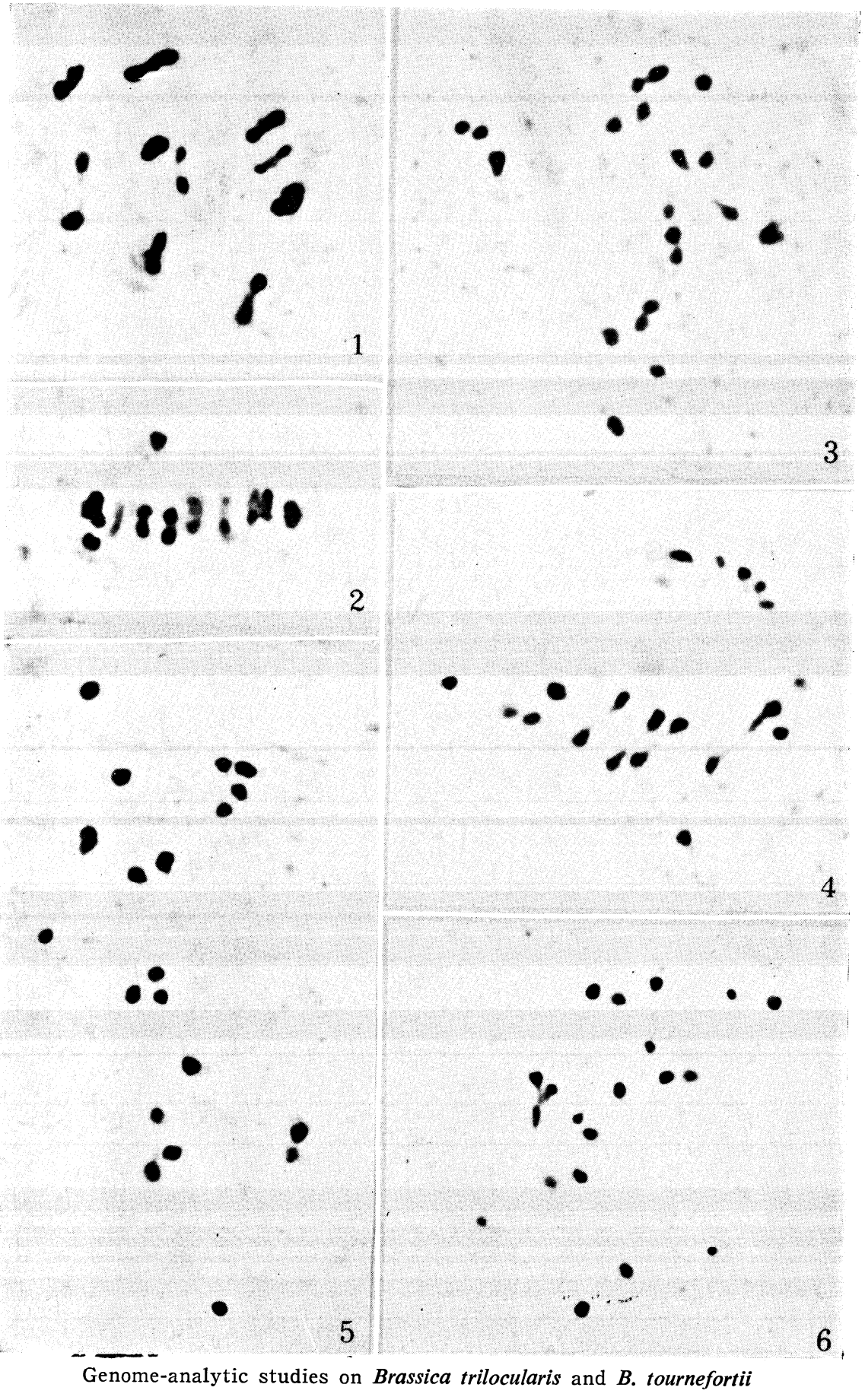

